\title{
O significado do 4 de julho para o negro, de Frederick Douglass
}

\author{
The meaning of July fourth for the negro, \\ from Frederick Douglass
}

\author{
Marcos Fanton \\ Tatiana Vargas Maia
}

\section{Introdução}

O discurso de Frederick Douglass, ${ }^{1}$ aqui traduzido, é considerado um dos textos abolicionistas mais famosos da história norte-americana. Convidado pela Rochester Ladies' Anti-Slavery Society, Douglass proferiu seu discurso, em comemoração ao dia da independência norte-americana, por mais de duas horas diante de um público de cerca de seiscentas pessoas, entre elas homens e mulheres negras e brancas, que se faziam presentes no Salão Corinthian, em Rochester, Nova Iorque.

Assim como hoje, o quatro de julho, para os norte-americanos, sempre foi associado à rituais e cerimonias patrióticas, com eventos privados e públicos, para celebrar a data de nascimento dos Estados Unidos da América e da Declaração da Independência. Porém, para a maioria dos negros e dos movimentos abolicionistas, este era um feriado de pessoas brancas. Como era possível comemorar o dia da assinatura de um documento que visava garantir liberdade e direitos iguais para todos, se o país permitia a escravidão? O quatro de julho, por isso, era um dia de luto, não de celebração. Para os negros, era a data da promessa da liberdade e de sua negação. Como forma de protesto, muitos movimentos abolicionistas adiavam para o dia 5 de julho a realização de alguma manifestação. O discurso de Douglass, nesse sentido, é

\footnotetext{
${ }^{1}$ Tradução, introdução, revisão e notas realizadas por Marcos Fanton (PPG em Filosofia da Universidade Federal de Pernambuco, em Recife, PE, Brasil < fanton.marcos@gmail.com>) e Tatiana Vargas Maia (PPG em Memória Social e Bens Culturais na Unilasalle em Canoas, RS, Brasil<vargasmaia@gmail.com>).
} 
uma desconstrução retórica e argumentativa do "dilema [norte-]americano". É uma reapropriação crítica não só da data de celebração, mas das crenças, da narrativa da história norte-americana e de seus principais documentos.

Douglass começa seu discurso com um artifício retórico muito comum à época ao colocar em dúvida suas habilidades oratórias e sua capacidade intelectual. $\mathrm{O}$ tom de humildade e desculpa procura manter seus ouvintes atentos aos seus argumentos. Esta "máscara de subserviência" tinha também o propósito, segundo James Colaiaco, ${ }^{2}$ de mostrar como negros precisavam adotar ares de passividade diante de brancos, na medida em que suas habilidades intelectuais (e sua condição humana) eram constantemente menosprezadas e atacadas - sem contar a fragilidade de suas vidas.

Não obstante, Douglass já era conhecido, antes do discurso de 1852, como um dos maiores oradores do abolicionismo. Tinha viajado para diversos estados norte-americanos e países europeus para realizar conferências, escrito uma autobiografia condenando a instituição da escravidão e era editor de jornais abolicionistas, entre eles, o Estrela do Norte (Lee, 2009). ${ }^{3}$

Em seguida, Douglass passa a se posicionar a respeito do quatro julho a partir de uma perspectiva dissonante. Enquanto negro e ex-escravo, Douglass dirige-se à plateia através dos pronomes "eu" e "vocês". Estes marcam a tensão entre a comemoração da liberdade conquistada pelos revolucionários norte-americanos e a liberdade negada, por estes mesmos revolucionários, aos negros, que continuam escravizados ou, na melhor das hipóteses, com direitos políticos negados. Ao mesmo tempo, porém, Douglass dirige-se à plateia como um "concidadão", isto é, alguém que pode (e, de um ponto de vista moral, deve) discutir questões fundamentais do país e apontar suas injustiças. Para Colaiaco, esta dualidade antecipa aquilo que W.E.B. Du Bois chamará, em The souls of black folks (1903), de "dupla consciência" dos negros norteamericanos: uma percepção de si mesmo a partir de outro, o que implica, neste caso, em uma situação de inclusão e de exclusão dos Estados Unidos da América (Colaiaco, 2006, p. 33-34).

Em nível macro, este dualismo expressa o "dilema [norte-]americano": a contradição entre a assinatura de uma Declaração da Independência, que pretende garantir direitos iguais para todos, e a manutenção da instituição da escravidão. Douglass irá se reapropriar da narrativa histórica da nação norte-americana para mostrar que não apenas a defesa da escravidão é

\footnotetext{
$\overline{{ }^{2} \text { Colaiaco (2006, p. 30) }}$. O livro, como um todo, é extremamente instrutivo e é utilizado como base para a realização destes comentários introdutórios.

${ }^{3}$ Esta autobiografia, felizmente, encontra-se traduzida para o português (ver Douglass, 2012).
} 
contrária aos seus documentos fundadores, como também ao próprio espírito revolucionário. "É uma calúnia sobre sua memória", irá afirmar Douglass. Com isso, Douglass não apenas mostra a "distância incomensurável" entre ele (os negros) e a plateia (a sociedade norte-americana), mas entre a plateia e os Pais Fundadores (Wilson, 2015, p. 30). Assim, as justificativas da revolução (a opressão da Coroa inglesa) e as analogias históricas (o povo hebreu contra egípcios) serão utilizadas em favor da causa abolicionista. É, ao mesmo tempo, uma mensagem sobre as possibilidades de uma nova revolução.

O modo de reapropriação da narrativa, efetivado por Douglass, segue a tradição do chamado "sermão político", estabelecido aos moldes das denúncias e profecias de Jeremias. O discurso de Douglass reflete a estrutura deste tipo de sermão e pode ser dividido em três partes: [I] uma referência ao povo norteamericano, que, ao se estabelecer a partir de um documento fundador oficial, realiza a promessa de garantir determinados direitos a todos; [II] a denúncia do povo norte-americano, que não cumpriu sua promessa ao permitir o pecado da escravidão em suas terras; e [III] a possibilidade de sua redenção, dada a "juventude" da nação, e a esperança no cumprimento da profecia (Colaiaco, 2006, p. 46-7).

Ao olhar para o presente (e para o futuro do país), Douglass volta a ressaltar a "distância imensurável" entre brancos e negros e choca a plateia ao questionar o próprio convite para falar nesta data: "Este quarto de julho é seu, não meu". A partir disso, Douglass passa a mostrar o "ponto de vista do escravo" e as atrocidades da escravidão em todo o país.

A esta altura do discurso, Douglass torna um pouco mais claro o público a qual o discurso é dirigido (Colaiaco, 2006, p. 35). Ele não é os integrantes dos Estados do Sul, com sua defesa brutal da escravidão e da visão de negros como propriedade. Douglass visa, principalmente, o Norte e sua complacência moral com a perpetuação do regime escravista - aqueles "cujo julgamento não é cego por preconceito ou que não é, de coração, um senhor de escravos”. É por isso, então, que seu foco não está, exatamente, nos motivos contra a escravidão ou contra a visão da inferioridade dos negros, mas em quando e como esta instituição será extinta e a condição dos negros alcançará parâmetros mais equitativos. Em um editorial de 1850, de seu jornal Estrela do Norte, Douglass afirma, de maneira convicta e indignada: "Eles [os senhores de escravo] falam de direitos (!!) da escravidão, como se fosse possível a escravidão ter direitos. [...] A escravidão não tem direitos" (Colaiaco, 2006, p. 66). As menções a respeito da "nacionalização da escravidão", consequência direta da Lei do Escravo Fugitivo, e da complacência da igreja católica com a situação dos negros, vão nessa direção. 
Além disso, esta exortação ao engajamento imediato dos simpatizantes à causa abolicionista encontra paralelos com a indignação moral de Martin Luther King a respeito de uma "maioria moderada":

Eu quase cheguei à conclusão lamentável de que a grande pedra no caminho dos negros rumo à liberdade não era o White Citzens Counciler ou o Ku Klux Klanner, mas os brancos moderados que são mais devotados à 'ordem' do que à justiça, que preferem uma paz negativa, que é a ausência de tensão, à paz positiva, que é a presença da justiça, que constantemente dizem 'eu concordo com você no objetivo que busca, mas não posso concordar com os seus métodos de ação direta', que paternalisticamente sentem que podem estabelecer a agenda para a liberdade de outro homem, que vivem pelo mito do tempo e que constantemente aconselham os negros a esperar até 'um tempo mais conveniente'. A compreensão superficial de pessoas de boa-fé é mais frustrante do que a absoluta incompreensão de pessoas de vontade doentia. Aceitação morna é pior do que rejeição completa (King Jr., 2014, p. 304).

Por fim, é importante comentar que o discurso de quatro de julho marca uma transformação no pensamento de Douglass a respeito dos meios para se alcançar a abolição dos escravos negros (Colaiaco, 2006, cap. 4). Na época, os movimentos abolicionistas estavam divididos em dois grupos. O primeiro deles, liderado por William Loyd Garrison, tinha como principal estratégia a denúncia moral do sistema escravista e a rejeição a qualquer tipo de ação política. Os garrisonianos, como eram conhecidos, defendiam a dissolução do Norte com os Estados do Sul através do slogan "Nenhuma união com senhores de escravos". Afirmavam, ainda, que a constituição norte-americana era uma "convenção com a morte e um acordo com o inferno". Nesse sentido, qualquer ação política, como o exercício do voto ou a formação de partidos políticos, era considerada atos condescendentes à escravidão.

Douglass, em sua juventude, foi favorável a esta visão. Inclusive, Garrison foi seu grande mentor e protetor. Contudo, para indignação deste último, Douglass passou a adquirir, gradativamente, uma visão mais favorável da ação política e da Constituição. A ruptura com Garrison marcou, também, uma modificação da própria identidade de Douglass e é, geralmente, vista através de sua segunda biografia My bondage and my freedom. ${ }^{4}$

O segundo grupo de abolicionistas, nesse sentido, percebia a necessidade e a importância da ação política e compreendia a Constituição norte-americana

\footnotetext{
${ }^{4}$ Questões sobre identidade são muito discutidas na literatura sobre Douglass. Ver, por exemplo, os primeiros capítulos de Lee (2009).
} 
como o instrumento para atingir o fim da escravidão. Entre seus membros, pode-se destacar Gerrit Smith, um dos fundadores do Partido da Liberdade, que influenciou enormemente Douglass em sua nova leitura.

Esta mudança na visão de Douglass deveu-se, em parte, a uma nova compreensão da relação entre ação moral e ação política. Para ele, a esfera moral pode ter um padrão alto de exigência, na medida em que é direcionada a indivíduos. Já a política, como envolve grupos de pessoas, deve deixar de lado a perfeição e buscar os limites praticáveis em cada contexto (Colaiaco, 2006, p. 77 e p. 93). Para Douglass, desistir da ação política, em detrimento de uma defesa incondicional da ação moral, significa falhar em compreender a situação política de maneira mais realista. Não podemos nos cegar completamente às consequências políticas dos nossos ideais morais. O projeto de secessão do Norte, feito pelos garrisonianos, para garantir uma consciência moral intocada, poderia levar ao abandono da responsabilidade moral dos negros escravizados do Sul: "[O movimento abolicionista] começou com o intuito de libertar o escravo, [...] mas pode acabar deixando o escravo se libertar por si próprio" (Colaiaco, 2006, p. 92-3).

Douglass defende, assim, uma leitura da Constituição baseada "em seus próprios termos", dando prioridade ao seu preâmbulo e à Declaração da Independência. Tais documentos (e os direitos naturais expressos neles) têm precedência para dar sentido ao texto da Constituição e, com isso, mostram que a promessa de direitos e liberdades deve ser estendida a todos. A consequência desta interpretação, contrária até mesmo à de Lincoln, torna a escravidão não apenas imoral, mas inconstitucional - e, assim, o dilema norte-americano se mantém como uma tensão não resolvida politicamente. Portanto, a emancipação dos negros é necessária para a própria preservação da democracia norte-americana (Wilson, 2012, p.26). A interpretação da Constituição de Douglass ia contra diferentes interpretações: contra os sulistas, que acreditavam que não havia uma violação das ideias republicanas, pois negros não eram pessoas; contra Lincoln, que acreditava que a escravidão não era um problema do governo federal; e contra Garrison, que não acreditava no poder político e na imparcialidade deste documento (Colaiaco, 2006, p. 110).

\section{Referências}

BÍBLIA. Português. Bíblia Sagrada - edição pastoral < http://www.paulus.com.br/ biblia-pastoral $>$ (26 abr. 2017).

COLAIACO, James. Frederick Douglass and the fourth of july. New York: Palgrave MacMillan, 2006. 
DOUGLASS, Frederick. A narrativa da vida de Frederick Douglass, um escravo americano: escrita por ele mesmo. Trad. Leonardo Poglia Vida. Porto Alegre: [s.ed.] 2012.

DOUGLASS, Frederick. The meaning of the 4th of July for the negro $<$ http://rbscp.lib. rochester.edu/2945> (21 abr. 2017).

KING JR., Martin Luther. Carta da prisão da cidade de Birmingham. In: James Rachels; Stuart Rachels (Org.). A coisa certa a fazer: leituras básicas sobre filosofia moral. Porto Alegre: AMGH, 2014.

LEE, Maurice. Slavery, philosophy, and American literature, 1830-1860. Cambridge: Cambridge University Press, 2005.

LEE, Maurice. The Cambridge companion to Frederick Douglass. Cambridge: Cambridge University Press, 2005.

WILSON, Ivy. Specters of democracy: blackness and the aesthetics of politics in the antebellum U.S. Oxford: Oxford University Press, 2011. 


\section{Documento:}

\section{Discurso proferido no salão Corinthian, em Rochester, NY, EUA, por Frederick Douglass, em 5 de julho de 1852. ${ }^{5}$}

\section{O significado do 4 de julho para o negro}

Frederick Douglass

Senhor Presidente, Amigos e Companheiros:

Aquele que poderia dirigir-se a esta audiência sem uma sensação de acovardamento tem nervos mais fortes do que eu. Não me lembro de ter comparecido como um orador antes de qualquer reunião de maneira mais encolhida, nem com maior desconfiança da minha capacidade, do que eu faço neste dia. Um sentimento se esgueirou sobre mim, bastante desfavorável ao exercício de meus limitados poderes de expressão. A tarefa diante de mim é uma que requer profunda reflexão prévia e estudo para o seu desempenho apropriado. Eu sei que as desculpas deste tipo geralmente são consideradas rasas e sem sentido. Confio, no entanto, que as minhas não serão assim consideradas. Se eu parecesse à vontade, a minha aparência me representaria muito mal. A pouca experiência que tive em falar em reuniões públicas, em escolas do interior, não me serve de nada na presente ocasião.

Os papéis e cartazes dizem que eu devo proferir um discurso sobre o 4 de julho. Isso certamente soa grandioso e fora do comum para mim. É verdade que, muitas vezes, tive o privilégio de falar neste belo salão e de me dirigir a muitos que agora me honram com sua presença. Mas, nem seus rostos conhecidos nem a medida perfeita que eu acho que tenho do salão Corinthian parecem me livrar do embaraço.

O fato é que, senhoras e senhores, a distância entre esta plataforma e a plantation ${ }^{6}$ da qual escapei é considerável - e as dificuldades a serem superadas, ao passar desta última para a primeira, não são, de forma alguma, triviais. Que eu esteja aqui hoje é, para mim, uma questão tanto de espanto quanto de gratidão. Vocês não ficarão, portanto, surpresos, se, no que tenho a dizer, eu não evidencie nenhuma preparação elaborada nem adorne minha fala com qualquer exórdio eloquente. Com pouca experiência e com ainda menos aprendizado, consegui lançar meus pensamentos às pressas e de

\footnotetext{
${ }^{5} \mathrm{O}$ texto original está disponível em: <http://rbscp.lib.rochester.edu/2945> (21 abr. 2017).

${ }^{6}$ Plantation é um sistema agrícola monocultor voltado para a exportação caracterizado pela utilização de latifúndios e de mão-de-obra escrava.
} 
maneira imperfeita. E, confiando na sua paciente e generosa indulgência, vou prosseguir de modo a colocá-los diante de vocês.

Isto, para o propósito desta celebração, é o 4 de julho. É o aniversário da sua Independência Nacional e da sua liberdade política. Isto, para vocês, é o que a Páscoa foi para o povo emancipado de Deus. Isso leva suas mentes de volta para o barro e para o ato de sua grande libertação; e para os sinais e para as maravilhas associadas com o ato daquele dia. Esta celebração também marca o início de mais um ano de sua vida nacional e lembra-os que a República da América tem agora 76 anos de idade. Estou feliz, meus concidadãos, pelo fato de sua nação ser tão jovem. Setenta e seis anos, apesar de representar uma boa velhice para um homem, é apenas uma mera partícula na vida de uma nação. Setenta anos ${ }^{7}$ é o tempo alocado para homens individuais; mas as nações contam seus anos por milhares. De acordo com este fato, vocês estão, ainda agora, apenas no início de sua carreira nacional, ainda no período de sua infância. Repito, estou feliz que seja assim. Há esperança nesse pensamento e a esperança é muito necessária sob as nuvens escuras que se elevam no horizonte. $\mathrm{O}$ olho do reformador é recebido com flashes raivosos, anunciando tempos desastrosos. Mas, seu coração pode bater mais leve com o pensamento de que a América é jovem e que ela ainda está na fase impressionável de sua existência. Não pode ele esperar que as lições elevadas da sabedoria, da justiça e da verdade deem ainda a direção ao seu destino? Se a nação fosse mais velha, o coração do patriota poderia ser mais triste e a fronte do reformador mais pesada. Seu futuro poderia estar envolto em tristeza e a esperança de seus profetas esvairia em pesar. Há consolação neste pensamento de que a América é jovem. Grandes riachos não são facilmente desviados dos canais desgastados profundamente ao longo das eras. Podem, às vezes, levantar-se em uma majestade quieta e imponente e inundar a terra, refrescando e fertilizando o solo com suas propriedades misteriosas. Podem, também, elevar-se em ira e fúria e levar, em suas ondas raivosas, a riqueza acumulada de anos de trabalho e dificuldades. No entanto, fluem gradualmente para o mesmo canal antigo e fluem tão serenamente como sempre. Mas, enquanto o rio não pode ser desviado, ele pode secar e não deixar nada para trás, além do ramo seco e da rocha disforme para uivarem, ao vento dos abismos profundos, o triste conto de glórias passadas. O que acontece com os rios também acontece com as nações.

\footnotetext{
${ }^{7}$ A expressão é 'three score years and ten', que significa o tempo de uma vida humana, conforme aparece nos Salmos 90:10 (Sententa anos é o tempo de nossa vida/The days of our years are threescore years and ten). 'Score' era sinônimo de uma quantia numérica de vinte, assim como dúzia designa a quantia de doze. 'Threescore', assim, significava sessenta.
} 
Companheiros, eu não pretendo demorar-me nas associações que se aglomeram sobre esse dia. A história simples é que, 76 anos atrás, as pessoas deste país eram súditos britânicos. O estilo e o título de seu "povo soberano" (o qual vocês agora glorificam) ainda não existia. Vocês estavam sob a Coroa britânica. Seus pais ${ }^{8}$ estimavam o governo inglês como o seu governo de origem e a Inglaterra como sua pátria. Esse governo de origem, vocês sabem, apesar de uma distância considerável de sua casa e no exercício de suas prerrogativas parentais, impôs a seus filhos coloniais restrições, encargos e limitações tais, que, em seu julgamento maduro, considerou sábio, certo e apropriado.

Mas, os seus pais, que não tinham adotado a ideia da moda atual a respeito da infalibilidade do governo e do caráter absoluto de seus atos, presumiram discordar e diferir do governo de origem em relação à sabedoria e à justiça de alguns desses encargos e restrições. Foram tão ousados em sua excitação que pronunciaram tais medidas de governo injustas, irracionais e opressivas, e o fizeram de maneira tão contundente, que ninguém deveria se submeter silenciosamente a elas. Quase não preciso dizer, meus concidadãos, que minha opinião sobre essas medidas concorda plenamente com a de seus pais. Essa declaração de acordo da minha parte não valeria muito para ninguém. Certamente, não provaria nada quanto ao lado que eu poderia ter tomado se eu tivesse vivido durante a grande controvérsia de 1776. Dizer agora que a América estava certa, e a Inglaterra errada, é extremamente fácil. Todos podem dizê-lo; o vilão, não menos do que o valente nobre, pode discursar de maneira irreverente a respeito da tirania da Inglaterra sobre as colônias americanas. É moda fazê-lo. Mas, houve um tempo em que a ideia de se pronunciar contra a Inglaterra, e a favor da causa das colônias, tentou as almas dos homens. Os que assim o faziam eram considerados, à época, conspiradores de injúrias, agitadores e rebeldes, homens perigosos. Tomar o lado do certo contra o errado, do fraco contra o forte e dos oprimidos contra o opressor! Aqui reside o mérito e o que, de todos os outros, parece fora de moda em nossos dias. A causa da liberdade pode ser apunhalada pelos homens que se vangloriam nas obras de seus pais. Mas, devo prosseguir.

Sentindo-se dura e injustamente tratados pelo governo de origem, seus pais, como homens de honestidade e homens de espírito, sinceramente, procuraram reparação. Eles peticionaram e protestaram; eles o fizeram de maneira decorosa, respeitosa e leal. Sua conduta era inteiramente irrepreensível.

\footnotetext{
${ }^{8}$ De maneira indireta, Douglass refere-se, com esta expressão, aos Pais Fundadores dos Estados Unidos, isto é, os líderes políticos das Treze Colônias que lideraram a revolução contra a Coroa britânica e sua consequente independência. Entre os mais conhecidos, destacam-se Benjamin Franklin, Alexander Hamilton, Thomas Jefferson e George Washington.
} 
Isso, porém, não serviu ao propósito. Eles se viram tratados com indiferença soberana, frieza e desprezo. Ainda assim, eles perseveraram. Eles não eram os homens de olhar para trás.

Da mesma forma que a âncora de salvamento adquire um apoio mais firme quando o navio é agitado pela tempestade, a causa de seus pais também cresceu mais forte enquanto enfrentava as explosões arrepiantes de desgosto real. Os maiores e melhores estadistas britânicos admitiram sua justiça e a eloquência mais alta do Senado britânico veio a seu apoio. Mas, com aquela cegueira que parece ser a característica invariante dos tiranos, desde a vez em que o Faraó e suas tropas foram afogados no Mar Vermelho, o governo britânico persistiu nas extorsões reclamadas.

A loucura dessa conduta, acreditamos, é admitida agora até mesmo pela Inglaterra. Mas, tememos que a lição seja inteiramente perdida em nossos atuais governantes.

A opressão torna um homem sábio louco. Seus pais eram homens sábios e, se eles não ficaram loucos, eles ficaram inquietos sob esse tratamento. Sentiam-se vítimas de graves erros, totalmente incuráveis em sua capacidade colonial. Com homens corajosos, há sempre um remédio para a opressão. Só aqui nasceu a ideia de uma total separação das colônias da Coroa! Foi uma ideia surpreendente, muito mais do que nós, nessa distância de tempo, consideramo-la. Os tímidos e prudentes (como foi dito) daquele dia estavam, naturalmente, chocados e alarmados por ela.

Tais pessoas viveram então, viveram antes e, provavelmente, sempre terão um lugar neste planeta. E sua conduta, em relação a qualquer grande mudança (não importa quão grande o bem a ser alcançado ou o erro a ser corrigido por ela), pode ser calculada com tanta precisão quanto o trajeto das estrelas. Eles odeiam todas as mudanças, mas a prata, o ouro e o cobre mudam! Desse tipo de mudança, eles são sempre fortemente a favor.

Essas pessoas foram chamadas tories $^{9}$ nos dias de seus pais. E a denominação, provavelmente, transmitia a mesma ideia que se entende por um termo mais moderno, embora um tanto menos eufônico, que encontramos frequentemente em nossos jornais, aplicado a alguns de nossos velhos políticos.

Sua oposição ao então perigoso pensamento era séria e poderosa; mas, em meio a todo o seu terror e vozes aterrorizadas contra ela, a ideia alarmante e revolucionária prosperou, e o país com ela.

\footnotetext{
${ }_{9}$ Tories são os membros do antigo partido conservador do Reino Unido, Tory, que reunia a aristocracia britânica, e que esteve em atividade entre os anos de 1678 e 1834.
} 
No dia 2 de julho de 1776, o antigo Congresso Continental, ${ }^{10}$ para consternação dos amantes da tranquilidade e dos adoradores da propriedade, vestiu aquela ideia terrível com toda a autoridade de uma sanção nacional. Eles o fizeram sob a forma de uma resolução e, como raramente pensamos sobre as resoluções elaboradas em nossos dias, cuja transparência é igual a esta, isto pode refrescar suas mentes e ajudar a minha história se eu lê-la.

Resolveu-se que estas colônias unidas são, e de direito deveriam ser, estados livres e independentes; que elas estão absolvidas de toda lealdade à Coroa britânica; e que toda conexão política entre elas e o estado da GrãBretanha é, e deveria ser, dissolvida.

Cidadãos, seus pais fizeram cumprir aquela resolução. Eles conseguiram; e, hoje, vocês colhem os frutos de seu sucesso. A liberdade obtida é sua e vocês, portanto, podem devidamente celebrar este aniversário. O 4 de julho é o primeiro grande fato na história de sua nação - o próprio arganéu ${ }^{11}$ na cadeia de seu destino ainda não desenvolvido. Orgulho e patriotismo, não menos do que gratidão, incitam-nos a celebrar e a mantê-lo em perpétua lembrança. Eu disse que a Declaração de Independência é o arganéu [ligado] à corrente do destino de sua nação; assim, de fato, eu a considero. Os princípios contidos naquele instrumento são princípios de proteção. Permaneçam de acordo com aqueles princípios, sejam fiéis a eles em todas as ocasiões, em todos os lugares, contra todos os inimigos e a qualquer custo.

Do topo redondo da sua nau de estado, nuvens escuras e ameaçadoras podem ser vistas. Vagas pesadas, como montanhas à distância, revelam ao sota-vento formas enormes de rochas escarpadas! Aquele trinco ${ }^{12}$ retirado, aquela corrente quebrada, e tudo está perdido. Apegue-se a este dia-apeguese a ele, e aos seus princípios, com o punho de um marinheiro lançado pela tempestade a um mastro à meia-noite.

O surgimento de uma nação, em quaisquer circunstâncias, é um evento interessante. Mas, além de considerações gerais, havia circunstâncias peculiares que tornam o advento desta república um evento de especial atratividade.

Toda a cena, quando eu olho para ela, era simples, dignificada e sublime.

\footnotetext{
${ }^{10}$ Também conhecido como o "Congresso da Filadélfia", consistia em uma convenção de delegados de todas as Treze Colônias britânicas na costa Leste da América do Norte e tornou-se o órgão de governo dos Estados Unidos durante a Revolução Norte-Americana.

${ }^{11}$ Argola ou peça metálica em outros formatos (como em U ou triângulo), na qual se engatam correntes, cordas ou espias. Seguindo as metáforas náuticas de Douglass, o arganéu pode ser compreendido como a parte da âncora ou da boia, em forma de argola, para prender a corrente ou as amarras ligadas à embarcação.

${ }^{12}$ Douglass joga, aqui, com a partícula 'bolt' (parafuso, pino, ferrolho), de 'ringbolt' (traduzido acima como arganéu), impossível de se reproduzir no português.
} 
A população do país, na época, estava no insignificante número de três milhões. O país era pobre nas munições da guerra. A população era fraca e dispersa e o país, um deserto selvagem. Não havia, então, nenhum meio de acordo e combinação, como os que existem agora. Nem o vapor nem o raio tinham sido então submetidos à ordem e à disciplina. Ir do Potomac ao Delaware ${ }^{13}$ era uma jornada de muitos dias. Sob estas e inúmeras outras desvantagens, seus pais declararam-se pela liberdade e pela independência e triunfaram.

Companheiros, não estou faltando em respeito pelos pais desta república. Os signatários da Declaração de Independência eram homens corajosos. Eram grandes homens também - o bastante para dar fama a uma grande época. Não é habitual a uma nação gerar, ao mesmo tempo, um tal número de homens realmente grandes. O ponto de onde sou obrigado a vê-los não é, certamente, o mais favorável; e, ainda assim, eu não posso contemplar seus grandes feitos com menos do que admiração. Eles eram estadistas, patriotas e heróis e, pelo bem que eles fizeram e os princípios pelos quais lutaram, eu me unirei a vocês para honrar sua memória.

Eles amavam seu país mais do que seus interesses particulares. E, embora esta não seja a forma mais elevada de excelência humana, todos admitirão que é uma virtude rara e que, quando ela é exibida, exige respeito. Quem quiser, inteligentemente, dar a sua vida por seu país, é um homem cujo intento não é da natureza humana desprezar. Seus pais apostaram suas vidas, suas fortunas e sua honra sagrada na causa de seu país. Em sua admiração pela liberdade, perderam de vista todos os outros interesses.

Eram homens de paz; mas preferiam a revolução à submissão pacífica [e] à servidão. Eram homens calados; mas não se recusaram a agitar-se contra a opressão. Eles mostraram tolerância; e que conheciam seus limites. Acreditavam na ordem; mas não na ordem da tirania. Com eles, nada foi "resolvido" que não estava certo. Com eles, justiça, liberdade e humanidade eram "finais"; não escravidão e opressão. Vocês podem muito bem apreciar a memória de tais homens. Eram grandes em seus dias e em sua geração. Sua humanidade sólida se destaca tanto quanto mais contrastamos com esses tempos degenerados.

Quão circunspectos, exatos e proporcionais eram todos os seus movimentos! Quão diferente dos políticos oportunistas! Sua conduta política

\footnotetext{
${ }^{13}$ Os rios Potomac e Delaware delimitam, de maneira aproximada, a distância entre a cidade de Nova Iorque - então o grande centro político e econômico das Treze Colônias - e cidade de Washington, no distrito de Columbia, criada em 9 de julho de 1790 pelo Congresso Continental para servir como capital para o recém-fundado estado.
} 
olhava para além do momento passageiro e se estendia com força para o futuro distante. Eles se apoderaram de princípios eternos e deram um exemplo glorioso de sua defesa. Celebrem-os!

Apreciando plenamente as dificuldades a serem encontradas, acreditando firmemente no direito de sua causa, convidando honradamente o escrutínio de um mundo vigilante, apelando reverentemente ao céu para atestar sua sinceridade, compreendendo plenamente a responsabilidade solene que estavam prestes a assumir, medindo sabiamente as terríveis adversidades contra eles, seus pais, os pais desta república, estabeleceram, deliberadamente, sob a inspiração de um glorioso patriotismo e com uma fé sublime nos grandes princípios da justiça e da liberdade, a pedra fundamental da superestrutura nacional, que cresceu e ainda cresce em grandeza ao seu redor.

Deste trabalho fundamental, este dia é o aniversário. Nossos olhos são recebidos com demonstrações de entusiasmo alegre. Estandartes e flâmulas ondulam exultantemente na brisa. O ruído dos negócios, também, é silenciado. Até mesmo Mamon ${ }^{14}$ parece ter desistido de seu domínio sobre este dia. $\mathrm{O}$ pífano agudo e o tambor ativo unem os seus sotaques com o sinal ascendente de mil sinos de igreja. As orações são feitas, os hinos são cantados e os sermões são pregados em honra a este dia, enquanto a rápida marcha marcial de uma nação grande e multitudinária, ecoada por todos os montes, vales e montanhas de um vasto continente, revela a ocasião de um interesse emocionante e universal - o jubileu de uma nação.

Amigos e cidadãos, não preciso adentrar mais nas causas que levaram a este aniversário. Muitos de vocês as compreendem melhor do que eu. Vocês poderiam me instruir em relação a elas. Esse é um ramo do conhecimento em que vocês têm, talvez, um interesse muito mais profundo do que o seu orador. As causas que levaram à separação das colônias da Coroa britânica nunca faltaram para uma língua. Todas elas foram ensinadas nas suas escolas comuns, narradas às suas fogueiras, reveladas dos seus púlpitos e trovejadas dos seus corredores legislativos e são tão familiares para vocês quanto as palavras da casa. Eles formam o núcleo de sua poesia nacional e eloquência.

Lembro-me, também, que, como povo, os americanos estão notavelmente familiarizados com todos os fatos que os favorecem. Isto é estimado por alguns como uma característica nacional - talvez uma fraqueza nacional. É um fato, o que quer que contribua para a riqueza ou para a reputação dos americanos (e que possa ser obtido barato!) será encontrado pelos americanos. Eu não serei

\footnotetext{
14"Mammon", termo de origem hebraica, que significa dinheiro ou bens materiais. Geralmente, como na Bíblia, designa cobiça, ganância, avareza.
} 
acusado de caluniar os americanos, se digo que eu acho que os americanos podem pôr de lado qualquer questão que possa ser deixada, com segurança, em mãos americanas.

Deixo, portanto, os grandes feitos de seus pais a outros cavalheiros, cuja pretensão de descendência legítima terá menor probabilidade de serem contestadas do que a minha!

\section{O presente}

Minha questão, se eu tiver alguma aqui hoje, é com o presente. O tempo aceito com Deus e sua causa é o sempre vivo agora.

Não confie em nenhum futuro, ainda que agradável.

Deixe o passado morto enterrar seus mortos.

Aja, aja no presente vivo.

Coração firme e Deus acima. ${ }^{15}$

Temos que mexer no passado apenas enquanto podemos torná-lo útil para o presente e para o futuro. A todos os motivos inspiradores, aos feitos nobres que podem ser adquiridos com o passado, somos bem-vindos. Mas, agora é o momento, o momento importante. Seus pais viveram, morreram e fizeram o seu trabalho, e o fizeram muito bem. Vocês vivem e devem morrer, e vocês devem fazer os seus trabalhos. Vocês não têm o direito de desfrutar a quota de criança no trabalho de seus pais, a não ser que seus filhos sejam abençoados por seus trabalhos. Vocês não têm o direito de gastar e desperdiçar a fama arduamente adquirida por seus pais para cobrir sua indolência. Sydney Smith ${ }^{16}$ nos diz que os homens raramente elogiam a sabedoria e as virtudes de seus pais, a não ser para desculpar alguma loucura ou maldade própria. Esta verdade não é duvidosa. Há ilustrações dela próximas e remotas, antigas e modernas. Centenas de anos atrás, era considerado correto, para os filhos de Jacó, vangloriarem-se: temos "Abraão a nosso pai", mesmo quando há muito tinham perdido a fé e o espírito de Abraão. Aquelas pessoas se contentaram sob a sombra do grande nome de Abraão, enquanto repudiaram as ações que fizeram seu nome grandioso. Preciso lhes lembrar que uma coisa semelhante está sendo feita em todo o país hoje? Preciso lhes dizer que os judeus não são os únicos que construíram os túmulos dos profetas e enfeitaram os sepulcros dos justos? Washington não podia morrer até que ele tivesse quebrado as correntes

${ }^{15}$ Trecho do poema O salmo da vida, do poeta norte-americano Henry Wadsworth Longfellow (1807-1882), presente no livro, que o tornou célebre, Vozes da noite, de 1839.

${ }^{16}(1771-1845)$, um dos mais famosos oradores ingleses de sua época, conhecido por sua sagacidade e seu humor. 
de seus escravos. No entanto, seu monumento é construído pelo preço do sangue humano e os comerciantes, nos corpos e nas almas dos homens, gritam: "Temos Washington como "nosso pai" - Ai de mim, que deva ser assim, mas assim é.

O mal que os homens fazem vive depois deles, o bem é muitas vezes enterrado com os seus ossos. ${ }^{17}$

Companheiros, perdoem-me, permitam-me perguntar, por que sou chamado para falar aqui hoje? $\mathrm{O}$ que eu, ou aqueles que represento, temos a ver com a sua independência nacional? Os grandes princípios da liberdade política e da justiça natural, incorporados nessa Declaração de Independência, se estendem a nós? E, portanto, sou chamado a trazer a nossa oferta humilde ao altar nacional, a confessar os benefícios e expressar gratidão piedosa pelas bênçãos resultantes da sua independência para nós?

Gostaria a Deus, para o bem de vós e de nós, que uma resposta afirmativa pudesse ser verdadeiramente devolvida a essas perguntas! Então, minha tarefa seria leve e meu fardo fácil e agradável. Pois quem é tão frio, que a simpatia de uma nação não o pode aquecer? Quem é tão obstinado e morto para as reivindicações de gratidão, que não reconheceria gratamente tais benefícios inestimáveis? Quem é tão impassível e egoísta, que não daria a sua voz para dilatar a aleluia do jubileu de uma nação, quando as cadeias de servidão tinham sido arrancadas de seus membros? Eu não sou esse homem. Em um caso como esse, os mudos podem falar eloquentemente e os "aleijados saltarão como um cervo". ${ }^{18}$

Mas, tal não é o estado da questão. Eu digo isso com uma triste percepção da disparidade entre nós. Não estou incluído no âmbito deste glorioso aniversário! Sua elevada independência só revela a distância imensurável entre nós. As bênçãos em que hoje vocês se alegram não são desfrutadas em comum. A rica herança de justiça, liberdade, prosperidade e independência, legada por seus pais, é compartilhada por vocês, não por mim. A luz do sol que trouxe vida e cura para vocês, trouxe listras e morte para mim. Este quatro de julho é seu, não meu. Vocês podem se alegrar, eu devo lamentar. Arrastar um homem em grilhões para o grande templo iluminado da liberdade e convocá-lo para se juntar a vocês em hinos alegres constitui zombaria desumana e ironia sacrílega. Vocês pretendem, cidadãos, zombar de mim, pedindo-me para falar

\footnotetext{
${ }^{17}$ Shakespeare. Júlio César. Ato 3, Cena 2.

${ }^{18}$ Isaías, 35:6: "os aleijados saltarão como cervo, e a língua do mudo cantará, porque jorrarão águas no deserto e rios na terra seca". Todas as citações bíblicas foram retiradas da edição pastoral da editora Paulus <http://www.paulus.com.br/biblia-pastoral/_INDEX.HTM> (26 abr. 2017).
} 
hoje? Se assim for, há um paralelo com a sua conduta. E deixe-me adverti-los que é perigoso copiar o exemplo de uma nação cujos crimes, elevando-se até o céu, foram jogados para baixo pelo sopro do Poderoso, enterrando aquela nação em ruína irrecuperável! ${ }^{19}$ Eu posso hoje assumir o lamento queixoso de um povo extorquido e aflito!

E junto aos canais de Babilônia, sentamo-nos.

Sim, choramos quando nos lembramos de Sião.

Nós penduramos nossas harpas sobre os salgueiros em seu meio.

Lá, os que nos exilaram pediam canções, nossos raptores queriam diversão, dizendo:

'Cantem para nós um canto de Sião!'

Como podemos cantar um canto do Senhor em terra estrangeira?

Se me esquecer de você, ó Jerusalém, que seque a minha mão direita.

Que a minha língua se cole ao paladar, se eu não me lembrar de você. ${ }^{20}$

Concidadãos, acima de sua alegria nacional e tumultuada, eu ouço o lamento triste de milhões! cujas correntes, ontem onerosas e pesadas, são hoje tornadas mais intoleráveis pelos gritos jubileus que os atingem. Se eu me esquecer, se não me lembrar fielmente daqueles filhos sangrando de tristeza neste dia, "que minha mão direita se esqueça de sua destreza e que minha língua se grude ao teto de minha boca!" Esquecê-los, passar por cima de seus sofrimentos e me unir ao tema popular seria uma traição muito escandalosa e chocante e me deixaria em desgraça diante de Deus e do mundo. Minha questão, então, compatriotas, é a escravidão americana. Devo ver, este dia, e suas características populares, do ponto de vista do escravo. Permanecendo lá, identificado com o servo americano, fazendo minhas as suas injustiças, não hesito em declarar, com toda a minha alma, que o caráter e a conduta desta nação nunca me pareceram mais negros do que neste dia 4 de julho! Seja nos voltando para as declarações do passado ou para as afirmações do presente, a conduta da nação parece igualmente hedionda e revoltante. A América é falsa para o passado, falsa para o presente e, solenemente, destinase a ser falsa para o futuro. Permanecendo em pé com Deus e com o escravo esmagado e que sangra nesta ocasião, em nome da humanidade ultrajada, em nome da liberdade que está encadeada, em nome da Constituição e da Bíblia, que são desconsideradas e pisoteadas, atrevo-me a pôr em causa e

\footnotetext{
${ }^{19}$ Referência à narrativa da Torre de Babel, presente no livro do Gênesis da Bíblia.

${ }^{20}$ Salmos, 137:1-6.
} 
denunciar, com toda a ênfase que posso comandar, tudo o que serve para perpetuar a escravidão - o grande pecado e a vergonha da América! "Eu não vou esquivar, eu não vou desculpar"; ${ }^{21}$ vou usar a linguagem mais severa que posso impor. E, no entanto, nenhuma palavra escapará de mim que qualquer homem, cujo julgamento não é cego por preconceito ou que não é, no fundo, um senhor de escravos, não deva confessar que seja correta e justa.

Mas, eu acho que ouço alguém do meu público dizer que é justamente nessa circunstância que você e seu irmão abolicionista não conseguem causar uma impressão favorável na mente pública. Se você argumentasse mais e denunciasse menos, se persuadisse mais e repreendesse menos, sua causa teria muito mais probabilidade de ter sucesso. Mas, proponho, onde tudo está claro, não há nada a ser discutido. Que ponto, no credo antiescravagista, você me faria argumentar? Em que ramo do assunto as pessoas deste país precisam de luz? Devo comprometer-me a provar que o escravo é um homem? Esse ponto já foi concedido. Ninguém duvida disso. Os próprios senhores de escravos reconhecem isso na promulgação de leis para seu governo. Eles o reconhecem quando punem a desobediência por parte do escravo. Há setenta e dois crimes no Estado de Virgínia que, se cometidos por um negro (por mais ignorante que seja), sujeitam-no ao castigo da morte; enquanto isso, apenas dois dos mesmos crimes sujeitarão um homem branco ao castigo semelhante. $\mathrm{O}$ que é isso, senão o reconhecimento de que o escravo é um ser moral, intelectual e responsável. $A$ humanidade do escravo é concedida. É admitida no fato de que os livros estatutários do Sul são cobertos com decretos proibindo, sob severas multas e penalidades, o ensinamento do escravo a ler ou a escrever. Quando você pode apontar para tais leis, em referência aos animais do campo, então posso consentir em argumentar sobre a humanidade do escravo. Quando os cães nas ruas, quando as aves no ar, quando o gado em suas colinas, quando os peixes do mar e os répteis que rastejam, sejam incapazes de distinguir o escravo de um bruto, então eu vou argumentar com você que o escravo é um homem.

Por ora, basta afirmar a igual humanidade da raça negra. Não é surpreendente que, enquanto estamos lavrando, plantando e colhendo, usando todos os tipos de ferramentas mecânicas, construindo casas, construindo pontes, construindo navios, trabalhando em metais de latão, ferro, cobre, prata e ouro; que, enquanto lemos, escrevemos e inscrevemos, agindo como funcionário, comerciantes e secretários, tendo entre nós advogados, médicos, ministros, poetas, autores, editores, oradores e professores; que,

\footnotetext{
${ }^{21}$ Trecho do editorial "Ao público", de William Lloyd Garrison, que inaugurava o jornal antiescravagista The Liberator em $1^{\circ}$ de janeiro de 1831.
} 
enquanto estamos envolvidos em todos os tipos de empreendimentos comuns a outros homens, cavando ouro na Califórnia, capturando a baleia no Pacífico, alimentando ovelhas e gado na encosta, vivendo, movendo, agindo, pensando, planejando, vivendo em famílias como maridos, esposas e filhos e, acima de tudo, confessando e adorando o Deus cristão e olhando com esperança para a vida e a imortalidade além do túmulo, somos chamados a provar que somos homens!

Vocês gostariam que eu argumentasse que o homem tem direito à liberdade? Que ele é o legítimo dono de seu próprio corpo? Vocês já o declararam. Devo argumentar a injustiça da escravidão? Isso é uma pergunta para Republicanos? Deve ser resolvido pelas regras da lógica e da argumentação, como uma questão cercada de grande dificuldade, envolvendo uma aplicação duvidosa do princípio da justiça, difícil de ser entendida? Como eu devo me apresentar hoje, na presença dos americanos, dividindo e subdividindo um discurso, para mostrar que os homens têm um direito natural à liberdade? Falando sobre isto relativamente, e positivamente, negativamente e afirmativamente. Fazê-lo seria me ridicularizar e oferecer um insulto à sua compreensão. Não há um homem sequer sob a abóbada celeste que não saiba que a escravidão é errada para ele.

$\mathrm{O}$ que, devo eu argumentar que é errado fazer de homens brutos, roubá-los de sua liberdade, fazê-los trabalhar sem salário, mantê-los ignorantes de suas relações com seus semelhantes, bater-lhes com paus, esfolar sua carne com o chicote, carregar os membros com ferros, caçá-los com cachorros, vendê-los em leilão, livrar-se de suas famílias, suprimir seus dentes, queimar sua carne, esfomeá-los à obediência e à submissão aos seus senhores? Devo eu argumentar que um sistema marcado com sangue e manchado de poluição está errado? Não, eu não vou. Tenho um emprego melhor para o meu tempo e minha força do que o engajamento em tais argumentos.

O que, então, permanece para ser discutido? Que a escravidão não é divina; que Deus não a estabeleceu; que os nossos doutores da divindade estão enganados? Há blasfêmia no pensamento. O que é desumano não pode ser divino! Quem pode argumentar sobre tal proposição? Aqueles que são capazes, podem; eu não sou capaz. O tempo para tal argumento é passado.

Numa época como esta, uma ironia ardente, e não um argumento convincente, é necessária. Oh! Se eu tivesse a habilidade e pudesse chegar ao ouvido da nação, eu iria, hoje, derramar um rio de fogo de ridicularização mordaz, repreensão explosiva, sarcasmo assolador e censura severa. Pois não é a luz que é necessária, mas o fogo; não é a chuva suave, mas o trovão. Precisamos da tempestade, do redemoinho e do terremoto. A sensibilidade 
da nação deve ser acelerada; a consciência da nação deve ser despertada; a propriedade da nação deve ser assustada; a hipocrisia da nação deve ser exposta; e seus crimes contra Deus e o homem devem ser proclamados e denunciados.

O que, para o escravo americano, é o seu 4 de julho? Eu respondo: um dia que lhe revela, mais do que todos os outros dias do ano, a injustiça e a crueldade grosserias de cuja mentira ele é a vítima constante. Para ele, sua celebração é uma farsa; sua liberdade vangloriada, uma licença profana; sua grandeza nacional, uma vaidade inchada; seus sons de regozijo são vazios e sem coração; suas denúncias a tiranos, imprudências de fachada; seus gritos de liberdade e igualdade, zombarias ocas; suas orações e hinos, seus sermões e ações de graças, com todo o seu desfile religioso e solenidade, são, para ele, meros alardes, fraudes, enganos, impiedade e hipocrisia - um fino véu para encobrir crimes que desgraçariam uma nação de selvagens. Não há uma nação na terra culpada de práticas mais chocantes e sangrentas do que as pessoas destes Estados Unidos, nesta mesma hora.

Vá onde quiser, procure onde quiser, percorra todas as monarquias e despotismos do Velho Mundo, viaje pela América do Sul, procure todos os abusos e, quando encontrar o último, coloque seus fatos ao lado das práticas cotidianas dessa nação, e você dirá comigo que, em barbaridade revoltante e hipocrisia sem vergonha, a América reina sem rival.

\section{O comércio interno de escravos}

Tomemos o comércio americano de escravos que, segundo somos informados pelos jornais, encontra-se especialmente próspero neste exato momento. $\mathrm{O}$ ex-senador Benton ${ }^{22}$ nos diz que o preço dos homens nunca esteve tão alto como agora. ${ }^{23}$ Ele menciona o fato para mostrar que a escravidão não está em perigo. Este comércio é uma das peculiaridades das instituições americanas. Ele é realizado em todas as grandes cidades e povoados de metade desta confederação; e milhões são prejudicados todo ano por negociantes neste tráfico repugnante. Em diversos estados, este comércio é a principal fonte de riqueza. É chamado de "o comércio interno de escravos" (em oposição ao comércio internacional de escravos). É provável que assim

\footnotetext{
${ }^{22}$ Thomas Hart Benton (1782-1858).

${ }^{23}$ Um dos principais motivos foi a invenção de uma máquina mecânica, elaborada em 1793, por Eli Whitney, para a separação das fibras de algodão das sementes. Os efeitos para os negros norteamericanos foram devastadores: ao revolucionar a indústria do algodão nos Estados Unidos, a máquina levou ao aumento da demanda pelo produto e, com isso, ao aumento da demanda por escravos que trabalhavam nas plantations de algodão.
} 
também seja chamado para se distanciar do horror com o qual o comércio internacional de escravos é contemplado. Desde muito tempo, este comércio tem sido denunciado por este governo como pirataria. Foi denunciado com palavras impetuosas dos mais importantes lugares desta nação como um tráfico execrável. Para o deter, para lhe pôr um fim, esta nação mantém um esquadrão, de custo imenso, na costa da África. Em qualquer lugar deste país, fala-se convictamente sobre este comércio internacional de escravos como o tráfico mais desumano, oposto a qualquer coisa parecida com as leis de Deus e do homem. O dever de extirpá-la e destruí-la é admitido até por nossos doutores da divindade. No intuito de colocar um fim nisso, alguns destes últimos consentiram que seus irmãos de cor (nominalmente livres) deveriam deixar o país e estabelecerem-se na costa ocidental da África! No entanto, é um fato notável que, enquanto tanta repulsa é derramada pelos americanos sobre aqueles comprometidos com o comércio internacional de escravos, os homens comprometidos com o comércio de escravos entre estados passam sem condenação e, ainda, seus negócios são considerados honrosos.

Observem o funcionamento prático deste comércio interno de escravos - o comércio americano de escravos sustentado pela política americana e pela religião americana! Aqui, vocês verão homens e mulheres criados como suínos para o mercado. Vocês sabem o que é um criador de suínos? Eu lhes apresentarei um criador de homens. Eles habitam todos nossos estados sulistas. Eles perambulam o país e lotam as estradas da nação com caravanas de matéria-prima humana. Vocês verão um desses mercadores de carne humana, armado com pistola, chicote e faca bowi ${ }^{24}$ guiando uma companhia de centenas de homens, mulheres e crianças, desde o Potomac até o mercado de escravos em Nova Orleans. Estas pessoas desafortunadas serão vendidas individualmente ou em lotes, a fim de atender aos compradores. Elas são comida para os campos de algodão e para o funesto moinho de açúcar. Notem a procissão infeliz enquanto se move exausta e o miserável desumano que a guia. Ouçam seus gritos selvagens e suas juras sinistras, enquanto ele apressa seus prisioneiros assustados. Lá, vejam o velho com cadeados apertados e gastos. Deem uma olhada, se vocês puderem, naquela jovem mãe, cujos ombros estão nus sob o sol escaldante, suas lágrimas salgadas caem sobre a testa do bebê em seus braços. Vejam também aquela garota de treze anos chorando, sim, chorando, enquanto ela pensa na mãe da qual ela foi separada. A caravana move-se lentamente. Calor e sofrimento consumiram quase todas

\footnotetext{
${ }^{24}$ Modelo norte-americano de facas de caça e defesa, geralmente rústica e com grandes proporções (acima de $25 \mathrm{~cm}$ de comprimento), que são utilizadas nas fronteiras dos Estados Unidos desde o século 18.
} 
suas forças. De repente, vocês ouvem um rápido estalo, como o disparo de um rifle; os grilhões tinem e a corrente chacoalha simultaneamente; seus ouvidos são atingidos por um grito que parece ter talhado seu caminho para o centro de suas almas. O estalo que vocês ouviram foi o som de um chicote de escravos; o grito que vocês ouviram foi o da mulher que vocês viram com o bebê. Sua velocidade esmoreceu diante do peso de sua criança e suas correntes; o talho em seu ombro lhe diz para prosseguir em frente. Sigam esta caravana para Nova Orleans. Assistam o leilão; vejam homens examinados como cavalos; vejam as formas das mulheres rude e brutalmente expostas para o olhar indecoroso dos compradores americanos de escravos. Vejam esta caravana vendida e separada para sempre; e nunca esqueça o soluço profundo e triste que surgiu da multidão dispersa. Digam-me, cidadãos, onde, sob o sol, vocês podem testemunhar um espetáculo mais diabólico e revoltante? E esta é, não obstante, apenas uma olhadela no comércio americano de escravos, tal como ele existe até o momento na parte governada dos Estados Unidos.

$\mathrm{Eu}$ nasci entre tais paisagens e situações. Para mim, o comércio americano de escravos é uma terrível realidade. Quando criança, minha alma foi constantemente penetrada por uma consciência de seus horrores. Eu vivi na rua Philpot em Fell's Point, Baltimore, ${ }^{25} \mathrm{e}$, do cais, vi os navios negreiros nas docas, ancorados na costa, com suas cargas de carne humana, esperando por ventos favoráveis para flutuar até Chesapeake. À época, havia um grande mercado de escravos na frente da rua Pratt, de Austin Woldfolk. ${ }^{26}$ Seus agentes eram enviados a cada cidade e povoado de Maryland para anunciar a chegada dos escravos através dos jornais e, em panfletos chamativos, destacava-se dinheiro vivo por negros. Estes homens eram, geralmente, bem vestidos e com modos muito atraentes; sempre prontos para beber, negociar e apostar. $\mathrm{O}$ destino de muitos escravos dependeu da virada de uma única carta - e muitas crianças foram levadas à força dos braços de suas mães por barganhas arranjadas em um estado de brutal embriaguez.

Os traficantes de carne reúnem suas vítimas às dúzias e levam-nas, acorrentadas, para o depósito geral de Baltimore. Quando um número suficiente foi coletado, um navio é fretado com a finalidade de transportar a tripulação desamparada para Mobile ou para Nova Orleans. Da prisão de escravos para o navio eles são levados geralmente na escuridão da noite, pois, desde a agitação antiescravagista, certa precaução é observada.

\footnotetext{
${ }^{25}$ Localizada em Maryland, a cidade de Fell's Point estabeleceu-se como um centro comercial e de construção de navios.

${ }^{26}$ Woldfolk (1796-1847) foi um dos pioneiros no tráfico de escravos em Baltimore.
} 
$\mathrm{Na}$ escuridão profunda da meia-noite, tenho sido despertado frequentemente pelos passos mortos e pesados e os lamentos pungentes dos bandos acorrentados que passaram pela nossa porta. A angústia de meu coração juvenil era intensa. E eu era consolado, frequentemente, ao conversar com minha senhora pela manhã e ouvi-la dizer que esse costume era muito insano, que ela odiava ouvir o tilintar das correntes e os choros de partir o coração. Eu ficava contente em encontrar alguém que simpatizava com minha repulsa.

Concidadãos, este tráfico sanguinário está hoje em operação ativa nesta república orgulhosa. Na solidão de meu espírito, eu vejo nuvens de poeira levantadas nas estradas do sul. Eu vejo as pegadas sangrentas. Eu ouço o lamento doloroso da humanidade acorrentada a caminho dos mercados escravocratas, aonde as vítimas serão vendidas como cavalos, ovelhas e suínos, vendidas para a oferta mais alta. Ali, vejo os laços mais tenros serem quebrados impiedosamente para gratificar o luxo, o capricho e a ganância dos compradores e vendedores de homens. Minha alma adoece com esta vista.

É esta a terra que seus pais amaram,

A liberdade que eles lutaram para ganhar?

É esta a terra na qual eles se mudaram?

São estes os túmulos em que eles repousam? ${ }^{27}$

Contudo, um estado de coisas ainda mais desumano, infame e escandaloso permanece por ser apresentado. Através de um ato do Congresso americano, que não possui nem dois anos, a escravidão foi nacionalizada em sua forma mais horrenda e revoltante. ${ }^{28}$ Por tal ato, a Linha Mason-Dixon foi obliterada. ${ }^{29}$ Nova Iorque tornou-se Virgínia. E o poder para prender, caçar e vender homens, mulheres e crianças como escravos permanece não mais como uma mera instituição estatal, mas é, agora, uma instituição dos Estados Unidos em sua totalidade. O poder é coextensivo ao hino nacional e ao cristianismo

\footnotetext{
${ }^{27}$ Trecho do poema antiescravagista Stanza for the times, do poeta John Greenleaf Whittier (1807-1892), publicado em 1893.

${ }^{28}$ Douglass refere-se, conforme se verá no próximo parágrafo, à Lei do Escravo Fugitivo, promulgada pelo Congresso através do Compromisso de 1850, que tentava resolver uma série de tensões que surgiram entre os Estados do Norte e do Sul após a independência. Esta lei tornava legítimo não apenas que todo escravo que fugisse pudesse ser legitimamente recapturado, não importando onde estivesse (em estados do Sul ou do Norte), mas também que as autoridades locais e os cidadãos tinham o dever de colaborar. Tal lei também foi denominada de "Lei do Sabujo", pois cães de caça deste tipo eram utilizados para perseguir escravos.

${ }^{29}$ A Linha Mason-Dixon, traçada entre 1763 e 1767, é conhecida na história dos Estados Unidos como a fronteira entre os estados escravagistas e os estados abolicionistas. Também é utilizada como uma referência à fronteira cultural que divide o Norte e o Sul dos Estados Unidos.
} 
americano. Aonde estes forem, também poderá ir o impiedoso caçador de escravos. Aonde estes estiverem, homem nenhum é sagrado. Ele é um pássaro para a arma do esportista. Através do mais sujo e diabólico de todos os decretos humanos, a liberdade e a pessoa de todo homem são colocadas em perigo. Seu amplo domínio republicano é um campo de caça para homens. Não apenas para ladrões ou assaltantes, inimigos da sociedade, mas para homens culpados de nenhum crime. Seus legisladores ordenam todos bons cidadãos a se engajarem neste esporte diabólico. Seu presidente, seu secretário de estado, seus lordes, nobres e membros da igreja, impõem, como um dever que você deve ao seu livre e glorioso país e ao seu Deus, que você faça esta coisa amaldiçoada. Não menos do que quarenta americanos foram, nos últimos dois anos, caçados e, sem um momento de aviso, levados acorrentados e consignados à escravidão e tortura excruciante. Alguns destes tinham esposas e crianças que eram suas dependentes para a subsistência. Mas, não se fez caso disso. O direito do caçador a sua presa é superior ao direito de casamento e a todos os direitos nesta república, os direitos de Deus inclusos! Para homens negros, não há nem direito, justiça, humanidade nem religião.

A Lei do Escravo Fugitivo torna o que é piedade, para eles, um crime; e suborna o juiz que os julga. Um juiz americano ganha dez dólares por cada vítima que ele consigna à escravidão e cinco, quando falha em fazer isso. O juramento de duas testemunhas é suficiente, sob esta sanção, tão sombria quanto o inferno, para enviar os homens negros mais pios e exemplares às garras sem remorso da escravidão! Seu próprio testemunho não vale nada. Ele não pode trazer testemunhas a seu favor. O ministro da justiça americana está limitado pela lei a ouvir apenas um lado - e este lado é o lado do opressor. Que este maldito fato seja contado perpetuamente. Que se esbraveje, ao redor do mundo, que, na América que ama as pessoas, que é democrática e cristã e que mata tiranos e odeia reis, que os assentos da justiça estão preenchidos com juízes que mantêm seus cargos através de um suborno aberto e palpável e estão limitados, ao decidir sobre o caso da liberdade de um homem, a ouvir apenas seus acusadores!

Em patente violação da justiça, em desconsideração descarada às formas de administração das leis, em astutos arranjos para atrapalhar os indefesos e em intenção diabólica, esta Lei do Escravo Fugitivo permanece única nos anais da legislação tirânica. Tenho dúvidas se haverá outra nação sobre o globo terrestre que terá a audácia e a vileza de colocar tal lei no livro constitucional. Se algum homem nesta assembleia pensar diferentemente de mim a respeito desta questão e se sente hábil em desaprovar minha declaração, eu o confrontarei com prazer em qualquer tempo e lugar que lhe for conveniente. 


\section{Liberdade religiosa}

Considero esta lei uma das violações mais grosseiras da liberdade cristã e, se as igrejas e os ministros de nosso país não fossem estupidamente cegos ou perversamente indiferentes, eles também a considerariam.

No mesmo momento em que estão agradecendo a Deus pelo gozo da liberdade civil e religiosa e pelo direito de adorar a Deus de acordo com os ditames de suas próprias consciências, eles estão totalmente silenciosos em relação a uma lei que rouba a religião de seu principal significado e a torna totalmente inútil para um mundo imerso em maldade. Se esta lei dissesse respeito a "hortelã, erva-doce e cominho", ${ }^{30}$ cerceando o direito de cantar salmos, de participar do sacramento ou de se envolver em alguma das cerimônias da religião, ela seria castigada pelo trovão de mil púlpitos. Um grito geral subiria da igreja, exigindo revogação, revogação, revogação instantânea! - E seria difícil para aquele político que presumisse solicitar os votos do povo sem inscrever esse lema em seu estandarte. Além disso, se esta exigência não fosse cumprida, outra Escócia seria adicionada à história da liberdade religiosa e os antigos e severos covenanters ${ }^{31}$ seriam jogados na sombra. Um John Knox seria visto em cada porta da igreja e ouvido de cada púlpito e Fillmore não teria alojamento melhor do que foi mostrado por Knox, para a bela, mas traiçoeira Rainha Maria da Escócia. O fato de que a igreja do nosso país (com exceções fracionárias) não considera a "Lei dos Escravos Fugitivos" como uma declaração de guerra contra a liberdade religiosa, sugere que essa igreja considera a religião simplesmente como uma forma de adoração, uma cerimônia vazia e não um princípio vital, que requer benevolência ativa, justiça, amor e boa vontade para com o homem. Ela estima o sacrifício acima da misericórdia; o canto de salmos acima do fazer o bem; reuniões solenes acima da justiça prática. Uma adoração que pode ser conduzida por pessoas que se recusam a dar abrigo aos sem abrigo, a dar pão aos famintos, vestimentas aos desprovidos e que obedecem a uma lei que proíbe esses atos de misericórdia, é uma maldição, não uma bênção à humanidade. A Bíblia se refere a todas essas pessoas como "escribas, fariseus, hipócritas, que pagam o dízimo de hortelã, erva-doce e cominho, e que omitiram os assuntos mais importantes da lei, do julgamento, da misericórdia e da fé".

\footnotetext{
${ }^{30}$ Mateus, 23:23: "Ai de vocês, doutores da Lei e fariseus hipócritas! Vocês pagam o dízimo da hortelã, da erva-doce e do cominho, e deixam de lado os ensinamentos mais importantes da Lei, como a justiça, a misericórdia e a fidelidade. Vocês deveriam praticar isso, sem deixar aquilo".

${ }^{31}$ Integrantes do movimento religioso escocês de 1638 que defendia a organização da Igreja Presbiteriana Escocesa.
} 


\section{A igreja responsável}

Mas, a igreja deste país não é apenas indiferente às injustiças ao escravo, ela efetivamente toma o partido dos opressores. Ela se fez o baluarte da escravidão americana e o escudo dos caçadores de escravos americanos. Muitos de seus mais eloquentes teólogos, que se erguem como as próprias luzes da igreja, deram descaradamente a sanção da religião e da Bíblia a todo o sistema escravocrata. Eles ensinaram que o homem pode, propriamente, ser um escravo; que a relação de mestre e escravo é ordenada por Deus; que enviar de volta um escravo fugitivo ao seu senhor é, claramente, o dever de todos os seguidores do Senhor Jesus Cristo; e essa horrível blasfêmia é impingida sobre o mundo para o cristianismo.

Da minha parte, eu diria, bem-vinda infidelidade! Bem-vindo ateísmo! Bem-vinda qualquer coisa! ao invés do evangelho pregado de acordo com aqueles teólogos! Eles convertem o próprio nome da religião em um motor de tirania e crueldade bárbara. Servem para confirmar mais infiéis, nesta era, do que todos os escritos infiéis de Thomas Paine, Voltaire e Bolingbroke ${ }^{32}$ juntos, fizeram! Esses ministros fazem da religião uma coisa fria e de coração frágil, sem princípios de ação correta nem entranhas de compaixão. Eles despojam o amor de Deus de sua beleza e deixam o trono da religião com uma forma enorme, horrível, repulsiva. É uma religião para opressores, tiranos, ladrões e brutamontes. Não é aquela "religião pura e sem manchas", ${ }^{33}$ que vem de cima, e que é "antes de tudo, pura, pacífica, humilde, cheia de misericórdia e bons frutos, sem discriminações e sem hipocrisia". ${ }^{44}$ Mas, uma religião que favorece os ricos contra os pobres; que exalta o orgulhoso acima do humilde; que divide a humanidade em duas classes, tiranos e escravos; que diz ao homem acorrentado, fica ali, e, ao opressor, siga oprimindo; é uma religião que pode ser professada e apreciada por todos os ladrões e escravizadores da humanidade; que faz de Deus uma acepção de pessoas, nega sua paternidade da raça e abandona, a passos largos, a grande verdade da fraternidade do homem. Tudo isso afirmamos ser verdade para a igreja popular e para o culto popular de nossa terra e nação - uma religião, uma igreja e um culto que, na autoridade da sabedoria inspirada, declaramos ser uma abominação aos olhos de Deus. Na linguagem de Isaías, a igreja americana poderia ser bem endereçada, "Parem de trazer ofertas inúteis. O incenso é coisa nojenta para

\footnotetext{
${ }^{32}$ Todos entusiastas e defensores da razão e das liberdades de pensamento e de expressão.

${ }^{33}$ Tiago 1:27: "Religião pura e sem mancha diante de Deus, nosso Pai, é esta: socorrer os órfãos e as viúvas em aflição, e manter-se livre da corrupção do mundo".

${ }^{34}$ Tiago 3:17.
} 
mim; luas novas e sábados, o chamado das assembleias, não suporto injustiça junto com solenidade. Suas luas novas e suas festas designadas, a minha alma odeia. Para mim, tornaram-se um peso que eu não suporto mais. Quando vocês erguem para mim as mãos, eu desvio o meu olhar. Sim! Mesmo quando multiplicarem as orações, eu não escutarei. Suas mãos estão cheias de sangue. Parem de fazer o mal, aprendam a fazer o bem, busquem o juízo, socorram o oprimido, façam justiça ao órfão, defendam a causa da viúva". ${ }^{35}$

A igreja americana é culpada, quando vista em conexão com o que está fazendo para manter a escravidão; mas é superlativamente culpada, quando vista em conexão com sua capacidade de abolir a escravidão. O pecado de que é culpada é o de omissão, bem como de comissão. Albert Barnes proferiu o que o senso comum de cada homem atento ao estado real da questão receberá como verdade, quando declarou que "Não há poder fora da igreja que poderia sustentar a escravidão por hora, se não fosse sustentado nela". ${ }^{36}$

Que a imprensa religiosa, o púlpito, a escola dominical, a reunião da conferência, as grandes associações eclesiásticas, missionárias e bíblicas e as sociedades de amigos do país disponham de seus imensos poderes contra a escravidão e a posse de escravos; e todo o sistema do crime e do sangue estariam espalhados aos ventos; e que não o façam, envolve-os na mais terrível responsabilidade da qual a mente pode conceber.

Ao processar o empreendimento antiescravagista, fomos solicitados a poupar a igreja, a poupar o ministério; mas como, nós perguntamos, poderia tal coisa ser feita? Estamos no limiar de nossos esforços para a redenção do escravo pela igreja, e o ministério do país [encontra-se] em batalha contra nós; e somos compelidos a lutar ou a fugir. De qual parte, eu suplico saber, tem vindo um fogo tão mortal sobre nossas fileiras, durante os últimos dois anos, como do púlpito do Norte? Como os defensores dos opressores, apareceram os homens escolhidos da teologia americana - homens honrados pela sua assim chamada piedade e seu verdadeiro aprendizado. Os Lords de Buffalo, os Springs de New York, os Lathrops de Auburn, os Coxes e Spencers de Brooklyn, os Gannets e Sharps de Boston, os Deweys de Washington e outras grandes luzes religiosas da terra, têm, em absoluta negação da autoridade $\mathrm{d} E l e$, por quem professaram serem chamados ao ministério, nos ensinado deliberadamente, contra o exemplo dos hebreus e contra o protesto dos Apóstolos, eles ensinam que devemos obedecer a lei do homem antes da lei de Deus.

\footnotetext{
${ }^{35}$ Isaías 1:13-17.

${ }^{36}$ Teólogo norte-americano (1798-1870) que, em suas obras, condenou a escravidão e defendeu o dever da Igreja de se posicionar diante da situação norte-americana.
} 
Meu espírito se cansa de tal blasfêmia; e como esses homens podem ser apoiados como os "exemplos e representantes de Jesus Cristo", é um mistério que eu deixo para outros compreenderem. Ao falar da igreja americana, no entanto, que seja claramente entendido que eu quero dizer a grande massa das organizações religiosas de nossa terra. Há exceções, e eu agradeço a Deus por haver. Podem ser encontrados nobres homens espalhados por todos esses Estados do Norte, dos quais Henry Ward Beecher, de Brooklyn, Samuel J. May, de Siracusa, e meu estimado amigo ${ }^{37}$ no palanque, são exemplos brilhantes; e deixe-me dizer ainda que, sobre esses homens, está o dever de inspirar nossas fileiras com elevada fé religiosa e zelo para nos alegrar na grande missão da redenção do escravo de suas correntes.

\section{Religião na Inglaterra e religião na América}

Pode-se ficar chocado com a diferença entre a atitude da igreja americana em relação ao movimento antiescravagista e aquela das igrejas na Inglaterra em relação a um movimento similar nesse país. Lá, a igreja, fiel à sua missão de aperfeiçoar, elevar e melhorar a condição da humanidade, avançou prontamente, atou as feridas do escravo das Índias Ocidentais e restaurou-o à sua liberdade. Lá, a questão da emancipação era uma questão religiosa elevada. Foi exigida em nome da humanidade e de acordo com a lei do Deus vivo. Os Sharps, os Clarksons, os Wilberforces, os Buxton, os Burchell e os Knibbs eram igualmente famosos por sua piedade e por sua filantropia. $\mathrm{O}$ movimento antiescravagista lá não era um movimento anti-igreja, porque a igreja assumiu plenamente sua parte na continuação desse movimento: e o movimento antiescravagista neste país deixará de ser um movimento antiigreja quando a igreja deste país assumir uma posição favorável, ao invés de uma posição hostil àquele movimento.

Americanos! Sua política republicana, não menos do que sua religião republicana, são flagrantemente inconsistentes. Vocês se vangloriam do seu amor à liberdade, da sua civilização superior e do seu puro cristianismo, enquanto todo o poder político da nação (encarnado, assim, nos dois grandes partidos políticos) está solenemente comprometido a apoiar e perpetuar a escravidão de três milhões de seus compatriotas. Vocês lançam seus anátemas contra os tiranos coroados da Rússia e da Áustria ${ }^{38}$

\footnotetext{
${ }^{37}$ Reverendo R. R. Raymond (nota do texto original). Todos indivíduos citados eram reformadores sociais que apoiavam a abolição da escravidão.

${ }^{38}$ Referência à Revolução Húngara de 1848 , que, da mesma forma que outras regiões, buscava sua independência do Império Austríaco. Mesmo após uma série de vitórias sucessivas e a proclamação da independência e formação da república, a Hungria foi derrotada pelo imperador austríaco Franz Joseph I, que obteve auxílio do czar Nicolas I, então imperador da Rússia.
} 
e orgulham-se de suas instituições democratas, enquanto vocês próprios consentem em ser os meros instrumentos e guarda-costas dos tiranos da Virgínia e Carolina. Vocês convidam às suas costas os fugitivos da opressão do exterior, os honram com banquetes, os cumprimentam com ovações, os animam, os brindam, os saúdam, os protegem e derramam sobre eles o seu dinheiro como água, mas os fugitivos da sua própria terra, vocês anunciam, caçam, prendem, atiram e matam. Vocês se glorificam em seu refinamento e em sua educação universal, mas ainda mantêm um sistema tão bárbaro e terrível quanto o sempre manchado caráter de uma nação - um sistema iniciado na avareza, apoiado no orgulho e perpetuado na crueldade. Vocês derramam lágrimas pela Hungria decaída e fazem da triste história de suas injustiças o tema de seus poetas, estadistas e oradores, e, até mesmo seus filhos galantes, estão prontos para voar às armas para reivindicar sua causa contra seus opressores. Mas, em relação às dez mil injustiças do escravo americano, vocês compeliriam o mais rigoroso silêncio e saudariam, como um inimigo da nação, aquele que se atrevesse a fazer dessas injustiças assunto do discurso público! Vocês estão todos em chamas com a menção da liberdade para a França ou para a Irlanda, mas são tão frios quanto um iceberg ao pensar na liberdade para os escravizados da América. Vocês discursam eloquentemente sobre a dignidade do trabalho e, contudo, vocês sustentam um sistema que, em sua própria essência, lança um estigma sobre o trabalho. Vocês podem expor seu peito à tempestade da artilharia britânica para derrubar um imposto de três centavos sobre o chá; ${ }^{39} \mathrm{e}$, contudo, extorquem a última moeda ganhada duramente do punho apertado dos trabalhadores negros de seu país. Vocês declaram acreditar que "de um só homem, Deus fez todas as nações de homens para habitar sobre toda a face da terra" 40 e ordenou a todos os homens, em todo lugar, que se amassem uns aos outros; e, contudo, vocês notoriamente odeiam (e se glorificam em seu ódio) todos os homens cujas peles não têm a mesma cor que as suas. Vocês declaram perante ao mundo, e são compreendidos pelo mundo ao declarar, que vocês "acreditam que essas verdades são autoevidentes, que todos os homens são criados iguais e são dotados pelo Criador de certos direitos inalienáveis e que, entre estes estão a vida, a liberdade e a busca da felicidade", ${ }^{41} \mathrm{e}$, ainda assim, vocês mantêm firmemente numa escravidão que, segundo seu próprio Thomas Jefferson, "é pior do que aquelas eras em que

\footnotetext{
${ }^{39}$ Referência à Lei do Chá (Tea Act), criada em 1773, pelo parlamento britânico, que tornava exclusiva a exportação de chá à América do Norte pela Companhia Britânica das Índias Orientais.

${ }^{40}$ Atos dos Apóstolos, 17:26.

${ }^{41}$ Trecho da Declaração da Independência dos Estados Unidos da América.
} 
seus pais levantaram em rebelião para se opor" ${ }^{42}$ um sétimo dos habitantes de seu país.

Concidadãos! Não me alongarei ainda mais sobre suas inconsistências nacionais. A existência da escravidão neste país marca o seu republicanismo como uma farsa, a sua humanidade como um pretexto vil e seu cristianismo como uma mentira. Ela destrói seu poder moral no exterior, corrompe seus políticos em casa. Ela enfraquece o fundamento da religião, faz de seu nome um sibilar e uma palavra de adeus a uma terra zombeteira. É a força antagonista em seu governo, a única coisa que perturba seriamente e põe em perigo sua União. Impede seu progresso; é a inimiga da melhoria, a inimiga mortal da educação; fomenta o orgulho; cria insolência; promove o vício; abriga o crime; é uma maldição para a terra que a sustenta; e, ainda assim, vocês se apegam a ela, como se fosse a âncora de salvamento de todas as suas esperanças. Oh! Estejam avisados! Estejam avisados! Um réptil horrível está enrolado no peito de sua nação; a criatura venenosa está amamentando no peito macio de sua jovem república; por amor a Deus, arranque e lance de vocês o monstro horrendo e deixe o peso de vinte milhões esmagar e destruí-lo para sempre!

\section{A constituição}

Mas, em resposta a tudo isso, é dito que precisamente o que eu agora denuncie está, de fato, garantido e sancionado pela Constituição dos Estados Unidos; que o direito de possuir e caçar escravos faz parte daquela Constituição moldada pelos ilustres pais desta República.

Então, eu ouso afirmar, apesar de tudo o que eu disse antes, que seus pais se curvaram, se curvaram baixamente.

Para palpar conosco em um duplo sentido: e manter a palavra de promessa ao ouvido, mas quebrá-la para o coração. ${ }^{43}$

E, ao invés de serem os homens honestos que eu antes os declarei, eles foram os maiores impostores que já existiram na humanidade. Esta é a conclusão inevitável e dela não há escapatória; mas eu difiro daqueles que acusam os autores da Constituição dos Estados Unidos dessa baixeza. É uma calúnia sobre sua memória, pelo menos, eu acredito. Não há tempo

\footnotetext{
${ }^{42}$ Frase escrita por Jefferson, pela primeira vez, em uma carta datada de 24 de janeiro de 1786 a Jean Nicholas Démeneunier.

${ }^{43}$ Shakespeare. Macbeth. Ato 5, Cena 8.
} 
agora para discutir a questão constitucional com profundidade; nem tenho eu a capacidade de discuti-la como ela deve ser discutida. Este assunto foi tratado com magistral poder pelo escudeiro Lysander Spooner, por William Goodell, pelo escudeiro Samuel E. Sewall, e, por fim, mas de maneira não menos importante, pelo escudeiro Gerritt Smith. ${ }^{44}$ Estes senhores têm, como eu penso, plena e claramente vindicado a Constituição de qualquer projeto para apoiar a escravidão, nem que seja por uma hora.

Concidadãos! Não há assunto em relação ao qual os povos do Norte se deixaram impor de modo tão catastrófico como o do caráter pró-escravidão da Constituição. Nesse instrumento, eu defendo que não há autorização, licença, nem mesmo sanção da coisa odiosa; mas, interpretada como deveria ser interpretada, a Constituição é um glorioso documento de liberdade. Leia seu preâmbulo, considere seus propósitos. A escravidão está entre eles? Está na porta de entrada? Ou está no templo? Não está em nenhum. Embora não pretenda discutir esta questão na presente ocasião, permitam-me perguntar se não é um tanto singular que, se a Constituição pretendia ser, por seus autores e adotantes, um instrumento de escravidão, por que nem escravidão, nem escravismo nem escravo são encontrados em qualquer parte dela? $\mathrm{O}$ que se poderia pensar de um instrumento, redigido, legalmente redigido, para o propósito de conferir à cidade de Rochester uma faixa de terra, no qual nenhuma menção à terra foi feita? Agora, existem certas regras de interpretação para o entendimento correto de todos os instrumentos legais. Estas regras estão bem estabelecidas. São regras simples e do senso comum, de modo que vocês e eu, e todos nós, podemos entender e aplicar, sem ter passado anos no estudo do direito. Eu rejeito a ideia de que a questão da constitucionalidade ou da inconstitucionalidade da escravidão não é uma questão para o povo. Considero que todo cidadão americano tem o direito de formar uma opinião sobre a Constituição, de propagar essa opinião e de usar todos os meios honrosos para fazer prevalecer a sua opinião. Sem esse direito, a liberdade de um cidadão americano seria tão insegura quanto a de um francês..$^{45} \mathrm{O}$ ex-vice-presidente Dallas $^{46}$ nos diz que a Constituição é um objeto ao qual nenhuma mente americana pode estar excessivamente atenta e nenhum coração americano demasiado devotado. Ele diz, ainda, que a Constituição, em suas palavras,

\footnotetext{
${ }^{44}$ Todos ativistas políticos que defendiam políticas abolicionistas através de uma leitura próConstituição. Gerrit Smith (1797-1874), em particular, foi uma das pessoas com maior influência na nova leitura de Douglass sobre a Constituição e sobre o ativismo político. Smith ajudou a fundar o Partido da Liberdade e concorreu à presidência dos Estados Unidos em 1848.

${ }^{45}$ Douglass parece fazer referência ao contexto revolucionário francês de 1848.

${ }^{46}$ George Mifflin Dallas (1792-1864), vice-presidente de James K. Polk, pelo Partido dos Democratas.
} 
é clara e inteligível e destina-se à compreensão doméstica, não sofisticada, de nossos concidadãos. $\mathrm{O}$ senador Berrien ${ }^{47}$ nos diz que a Constituição é a lei fundamental que controla todos as outras. A escritura de nossas liberdades, que cada cidadão tem um interesse pessoal em compreender completamente. O testemunho do senador Breese, de Lewis Cass, ${ }^{48}$ e de muitos outros que podem ser nomeados, que são, em toda parte, considerados bons advogados, assim considera a Constituição. Considero, portanto, que não é presunção de um cidadão particular formar uma opinião sobre esse instrumento.

Agora, tome a Constituição de acordo com seus próprios termos e eu desafio a apresentação de uma única cláusula pró-escravidão nela. Por outro lado, verifica-se que contém princípios e propósitos totalmente hostis à existência da escravidão.

Eu já detive meu público por um período demasiado longo. Em algum momento futuro, eu aproveitarei com alegria a oportunidade de dar a este assunto uma discussão completa e justa.

Permitam-me que diga, em conclusão, que, não obstante o quadro sombrio que tenho neste dia apresentado, do estado da nação, não me desespero por este país. Há forças em operação que, inevitavelmente, conduzirão para a ruína da escravidão. "O braço do Senhor não ficou curto"49 e a condenação da escravidão é certa.

$\mathrm{Eu}$, portanto, concluo como comecei, com esperança. Ao extrair encorajamento da "Declaração de Independência", dos grandes princípios que ela contém e do gênio das instituições americanas, meu espírito também é animado pelas tendências óbvias da época. As nações não têm agora a mesma relação, umas com as outras, que tinham eras atrás. Nenhuma nação pode agora se fechar do mundo circundante e trotar no mesmo caminho antigo de seus pais sem interferência. Foi-se o tempo quando isso poderia ser feito. Costumes de longa data com caráter ofensivo poderiam, anteriormente, cercarse ao redor de si mesmos e cometer suas atrocidades com a impunidade social. O conhecimento era, então, confinado e desfrutado pelos poucos privilegiados, e a multidão caminhava na escuridão espiritual. Mas uma mudança tem vindo agora sobre os assuntos da humanidade. Cidades muradas e impérios tornaram-se fora de moda. O braço do comércio sepultou as portas da cidade

\footnotetext{
${ }^{47}$ Macpherson Berrien (1781-1856), defensor de uma leitura pró-escravidão da Constituição.

${ }^{48}$ Sidney Breese (1800-1878), Lewis Cass (1782-1866), ambos senadores que defendiam a não interferência federal em assuntos relacionados à escravidão.

${ }^{49}$ Isaías 59:1: "Veja! O braço de Javé não ficou curto para salvar, nem seus ouvidos ficaram surdos para ouvir".
} 
fortificada. A inteligência está penetrando nos cantos mais escuros do globo. Ela faz o seu caminho sobre e sob o mar, bem como sobre a terra. Vento, vapor e relâmpago são seus agentes fretados. Os oceanos não dividem mais, mas unem as nações. Ir de Boston para Londres é agora uma excursão de férias. $\mathrm{O}$ espaço é comparativamente aniquilado. Os pensamentos expressos de um lado do Atlântico são claramente ouvidos no outro.

O longe e quase fabuloso Pacífico rola em grandeza aos nossos pés. O Império Celestial, o mistério das eras, está sendo resolvido. A ordem do Todo-Poderoso, "Que haja Luz", ainda não gastou sua força. Nenhum abuso, nenhuma indignação no gosto, no esporte ou na avareza pode agora se esconder da luz que a tudo permeia. A sapatilha de ferro e o pé deformado da China devem ser vistos em contraste com a natureza. ${ }^{50} \mathrm{~A}$ África deve levantar-se e vestir sua roupa ainda não tecida. "A Etiópia estenderá a sua mão a Deus". ${ }^{51}$ Nas fervorosas aspirações de William Lloyd Garrison, eu digo, e deixo que cada coração se junte ao dizer:

Oxalá ao ano do jubileu

A larga ordem mundial!

Quando, de suas correntes aflitivas se libertarem, os oprimidos não mais vilmente dobrarão o joelho

E suportarão o jugo da tirania

Como brutos não mais.

Esse ano virá, e a liberdade reinará,

Para novamente ao homem seus direitos saqueados

Restaurar.

Oxalá ao dia em que o sangue humano

Deixará de fluir!

Em cada região serão compreendidas,

As reivindicações da fraternidade humana,

E cada retorno para o mal, o bem,

Não o golpe contra o golpe;

Esse dia virá para todos os feudos terminar,

E se transformar em um amigo fiel

Cada inimigo.

\footnotetext{
${ }^{50}$ Referência ao antigo costume chinês denominado "pés-de-lótus", que tinha por objetivo restringir, ao máximo possível, o crescimento dos pés das mulheres. Estes, quando pequenos, eram considerados símbolos de beleza e um requisito importante para o casamento. Por isso, as mulheres, ainda crianças, tinham seus pés rigorosamente amarrados, não raro, seus ossos eram quebrados, e acoplados a pequenos sapatos.

${ }^{51}$ Salmos 68:32.
} 
Oxalá a hora, a gloriosa hora,

Quando ninguém na terra

Deverá exercer um poder senhorial,

Nem se encolher na presença de um tirano;

Mas tudo para a torre de estatura da humanidade,

Por igual nascimento!

Essa hora virá, a cada um, a todos,

E da sua prisão, o escravo

Sairá.

Até que aquele ano, dia, hora chegue,

Com cabeça e coração e mão, eu lutarei,

Para quebrar a vara, e despedaçar o grilhão,

Privar o saqueador de sua presa.

Que o Céu seja testemunha!

E nunca do meu posto escolhido,

Qualquer que seja o perigo ou o custo,

Eu seja conduzido. 